http://ejournal.upi.edu/index.php/jaz/ - e-mail: jurnal.zonasi@gmail.com dan jurnal_zonasi@upi.edu DOI: http://dx.doi.org/10.17509/jaz.v1i1.11532

\title{
DAMPAK PERTUMBUHAN PENDUDUK TERHADAP PERKEMBANGAN RUANG KOTA SANGATTA
}

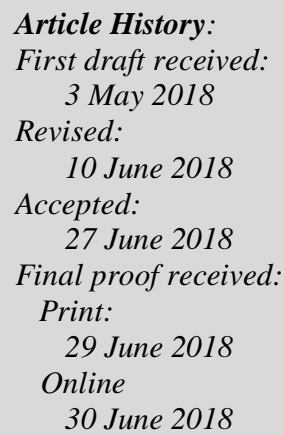

\author{
Raksa Maulana Subki ${ }^{1}$ \\ 1. Program Studi Arsitektur, Fakultas Teknik Sipil dan Perencanaan, Universitas \\ Kebangsaan. \\ Jl. Terusan Halimun No. 37 Bandung \\ Email: r.subki@universitaskebangsaan.ac.id
}

\begin{abstract}
East Kutai regency as an autonomous region which is also one of the largest coal producer region in Indonesia, becomes an attraction for immigrants who wants to work in such of mining companies in the region of Sangatta and its surroundings. With this condition, the developments of the city are very significant. The percentage of population growth reached $104.55 \%$ in the last 10 years. The city develops faster than the policies wich issued by the local government, such as planning of territory layout and detailed spatial plan, with the result that in its development are many aspect that not accordance with the spatial layout as well as the city planning. Many residential areas are formed but not well organized, because in the region has more than one function designation that fall into the category of mixed zone. With these conditions, it is necessary to take steps to solve the problems in creating a more comfortable and safe city space for the people of Sangatta.
\end{abstract}

Keywords: growth, urban planning, regional spatial planning, Sangatta

Abstrak: Kabupaten Kutai Timur sebagai daerah otonom yang juga menjadi salah satu wilayah penghasil batubara terbesar di Indonesia, menjadi daya tarik bagi para imigran untuk dapat bekerja di perusahaan-perusahaan tambang yang ada di wilayah Kota Sangatta dan sekitarnya, sehingga perkembangan kotanya sangat signifikan dikaitkan persentasi pertumbuhan penduduk yang mencapai $104,55 \%$ dalam 10 tahun terakhir. Perkembangan kotanya berkembang lebih cepat dari kebijakan-kebijakan yang dikeluarkan pemerintah daerah setempat, seperti RTRW dan RDTR, sehingga didalam perkembangannya kemudian banyak yang tidak sesuai dengan tata ruang wilayah maupun perencanaan kotanya. Banyak wilayah permukiman terbentuk namun tidak tertata dengan baik, karena dalam wilayah tersebut memiliki lebih dari 1 (satu) fungsi peruntukan yang masuk dalam kategori zona campuran. Dengan kondisi tersebut, maka diperlukan adanya langkah dan pemikiran dalam menyikapi permasalah-permasalah yang muncul sebagai sebuah solusi dalam menciptakan ruang kota yang lebih nyaman dan aman bagi masyarakat Kota Sangatta.

Kata kunci: pertumbuhan penduduk, perencanaan kota, tata ruang wilayah, Sangatta

\section{Pendahuluan}

\subsection{Latar Belakang}

Kabupaten Kutai Timur merupakan kabupaten hasil pemekaran dari Kabupaten Kutai sebagai Kabupaten induk berdasarkan Undang-undang Nomor 47 Tahun 1999. Sebagai daerah otonom, Kabupaten Kutai Timur yang berdiri sejak tahun 1999 mengalami pertambahan penduduk yang sangat signifikan. Salah satu faktor yang berpengaruh dalam pertambahan penduduk tersebut adalah karena Kabupaten Kutai Timur merupakan salah satu daerah yang memiliki cadangan batubara terbesar di Indonesia, sehingga menjadi daerah dengan tingkat imigran yang cukup besar. Hal ini dapat dilihat berdasarkan data kependudukan selama 10 tahun terakhir mengalami peningkatan jumlah penduduk sebesar $104,55 \%$ atau sebesar 212.397 jiwa, dari 
sebanyak 203.156 jiwa pada tahun 2006 menjadi 415.553 jiwa pada tahun 2016 (BPS,2017; Bappeda,2010; Dinas Kependudukan dan Pencatatan Sipil Kabupaten Kutai Timur, 2016). Peningkatan jumlah penduduk tersebut sangat berpengaruh terhadap perkembangan wilayah Kabupaten Kutai Timur terutama berkaitan dengan kebutuhan ruang untuk tempat tinggal.

Kawasan permukiman perkotaan di Kabupaten Kutai Timur direncanakan peruntukan ruang seluruhnya seluas lebih kurang 30.674,07 ha. Kecamatan Sangatta Utara sebagai pusat kegiatan wilayah dan sentra pemerintahan di Kabupaten Kutai Timur dengan tingkat pertumbuhan penduduk yang cukup signifikan, dialokasikan ruang lebih kurang 13.979,91 ha, sedangkan untuk Kecamatan Sangatta Selatan yang juga merupakan bagian dari pusat kegiatan wilayah, perencanaan permukiman perkotaan direncanakan seluas lebih kurang 1.750,68 ha dengan pengembangannya yang cukup relevan mengingat Kecamatan Sangatta Selatan sebagian besar wilayah administrasinya dalam areal Taman Nasional Kutai (TNK), sehingga pemanfaatan dan/atau pelepasannya menunggu keputusan Kementerian Kehutanan tentang perubahan peruntukan kawasan hutan menjadi kawasan bukan hutan (RTRW Kabupaten Kutai Timur Tahun 2015-2035).

Pengelolaan ruang yang dilakukan Pemerintah Kabupaten Kutai Timur belum dapat dicapai sesuai dengan target yang ditetapkan dalam RTRW Kabupaten Kutai Timur Tahun 2015-2035, dikarenakan wilayahwilayah permukiman muncul dan tumbuh seiring dengan pertumbuhan jumlah penduduk yang signifikan selama 10 tahun terakhir, tanpa terencana sebelumnya. Disamping itu, wilayah-wilayah permukiman yang terbentuk tidak tertata dengan baik, karena dalam wilayah tersebut ada lebih dari 1 (satu) fungsi peruntukan yang masuk dalam kategori zona campuran.

Hasil penelitian ini diharapkan menjadi masukan bagi perumusan kebijakan perencanaan dan perancangan kota Sangatta dengan tujuan untuk memaparkan seluruh konsekuensi dari kebijakan otonomi daerah secara umum, permasalahan yang dihadapi oleh kawasan objek studi serta beberapa pendekatan yang akan diterapkan dalam rangka mewujudkan ruang kota yang lebih berkualitas.

\subsection{Permasalahan}

Latar belakang permasalahan yang terjadi di Kota Sangatta Kabupaten Kutai Timur dapat dirumuskan sebagai berikut:

1. Wilayah-wilayah permukiman berkembang pesat seiring dengan pertumbuhan penduduk tanpa ada perencanaan kewilayahan sebelumnya, sehingga terbentuk zona-zona campuran.

2. Dengan terbentukknya zona campuran di hampir sepanjang jalan utama kota Sangatta (yang memiliki struktur kota linier), banyak wilayah permukiman yang bercampur dengan bangunan budidaya sarang burung walet, dimana keberadaan sarang burung walet di wilayah permukiman dirasakan kebanyakan warga sekitar mengganggu akibat suara yang ditimbulkan serta kotorannya yang diduga kuat dapat menyebarkan virus flu burung.

3. Kurangnya Ruang Terbuka Hijau (RTH) yang tersedia disepanjang jalan Yos Sudarso Sangatta, sebagai area resapan air.

Rumusan masalah tersebut kemudian diformulasikan menjadi beberapa pertanyaan penelitian untuk membantu mengarahkan pengamatan:

1. Adakah hubungan antara pesatnya pertumbuhan penduduk dengan perkembangan ruang Kota Sangatta?

2. Bagaimana pembagian zona yang terjadi di Kota Sangatta dikaitkan dengan RTRW Kabupaten Kutai Timur Tahun 2015-2035?

\subsection{Tinjauan Pustaka}

Didalam perkembangan, kota sangat erat kaitannya dengan banyaknya penduduk yang hidup dan tinggal di daerah perkotaan (urban), sehingga analisis tentang petumbuhan wilayah perkotaan harus dikaitkan dengan perkembangan jumlah penduduknya. Struktur ekonomi dan masalah yang dihadapi oleh wilayah perkotaan juga tidak sama dengan wilayah pedesaaan, sehingga analisa yang diperlukan tentunya juga berbeda (Becker dan Tomes, 1986).

Menurut sifatnya, urbanisasi merupakan konsentrasi secara spasial dari penduduk dan kegiatan ekonomi pada suatu tempat, namun tidak semua tempat dapat menjadi tempat konsentrasi spasial penduduk dan kegiatan ekonomi. Dengan adanya potensi kegaitan produksi y ang cukup besar pada tempat atau daerah, seperti pertanian atau pertambangan, maka dapat mendorong terjadinya aglomerasi pada tempat tersebut (Krier, 1979).

Tjiptoherijanto (1999) menyatakan bahwa secara umum urbanisasi diartikan sebagai perpindahan penduduk dari pedesaan menuju perkotaan, namun pengertian ini tidak selalu benar. Merujuk pada kondisi kontekstual, urbanisasi yang sesungguhnya adalah proporsi penduduk yang tinggal di perkotaan (urban area). 
Perkotaan (urban area) tidak sama dengan kota (city). Yang dimaksud dengan perkotaan (urban) adalah daerah atau wilayah yang memenuhi 3 (tiga) persyaratan, yaitu:

1. Kepadatan penduduk 5000 orang atau lebih per km persegi.

2. Jumlah rumah tangga yang bekerja di sektor pertanian sebesar $25 \%$ atau kurang.

3. Memiliki 8 (delapan) atau lebih jenis fasilitas perkotaan.

Pertambahan penduduk yang tinggal di perkotaan dapat disebabkan oleh beberapa faktor, yaitu: 1) pertumbuhan alamiah yang terjadi di daerah tersebut, 2) perpindahan penduduk baik dari kota lainnya maupun dari pedesaan, 3) aneksasi, dan 4) reklasifikasi.

Urbanisasi tidak semata-mata dipandang sebagai fenomena kependudukan, namun lebih daripada itu, urbanisasi harus dipandang sebagai fenomena politik, sosial, budaya dan ekonomi. Dari berbagai studi memperlihatkan bahwa semakin maju tingkat perekonomian suatu daerah, semakin tinggi pula tingkat urbanisasinya. Dengan demikian, urbanisasi merupakan fenomena alamiah sejalan dengan perkembangan ekonomi dan tingkat kesejahteraan penduduk di suatu daerah. Hal yang harus diperhatikan atau dihindari dalam kaitannya dengan urbanisasi adalah adanya konsentrasi penduduk yang tinggi atau berlebihan di suatu wilayah sehingga menimbulkan apa yang disebut dengan aglomerasi atau primacy.

Hirsch dan Mohl (1993) menyebutkan bahwa terdapat dua kondisi yang dapat mendorong terjadinya urbanisasi, yaitu:

a. Fenomena sisi penawaran (supply side), yang merupakan kombinasi dari perbandingan biaya komperatif (comperative cost advantage), spesialisasi produk dan skala ekonomi (economies of scale), fenomena ini seringkali disebut sebagai production-initiated urbanitation.

b. Fenomena sisi permintaan (demand side), yang pada dasarnya merupakan local market-initiated urbanitation, terutama karena perkembangan jumlah rumah tangga (house holds) yang berdiam di wilayah perkotaan tersebut.

Urbanisasi dalam fenomena supply side dapat dianalisa melalui berbagai aspek perbandigan biaya seperti: ketersedian fasilitas transportasi, akses terhadap sumber daya alam, iklim yang baik dan adanya tenaga kerja produktif. Sedangkan fenomena urbanisasi sisi permintaan memperlihatkan bahwa proses urbanisasi pada suatu wilayah perkotaan terjadi karena adanya konsentrasi permintaan yang selanjutnya akan mendorong peningkatan kegiatan produksi dan konsentrasi penduduk (Hirsch dan Mohl, 1993).

Ketika pertumbuhan terjadi maka akan meningkatkan permintaan terhadap kegiatan perdagangan dan jasa. Peningkatan kegiatan perdagangan dan jasa dapat pula mendorong terjadinya konsentrasi penduduk (urbanisasi) pada tempat tersebut melalui peningkatan migrasi penduduk masuk ke wilayah bersangkutan (inmigration). Demikian terlihat terjadinya peningkatan migrasi masuk merupakan factor pendorong utama ( $p u s h$ factor) terjadinya proses urbanisasi.

\subsubsection{Pendekatan Perencanaan Kota}

Kata atau istilah perencanaan banyak terdapat dala berbagai literatur dan didalam pendefinisiannya seringkali mengartikan secara berbeda namun pengertian yang paling mudah dipahami adalah suatu cara rasional untuk mempersiapkan atau apa yang ingin dicapai di masa mendatang. Dengan demikian perencanaan dapat diartikan sebagai suatu proses dalam menentukan apa yang ingin dicapai di masa mendatang melalui tahapan-tahapan yang dibutuhkan untuk mencapainya. Pendekatan perencanaan dilakukan dengan menguji berbagai arah pencapaian serta mengkaji berbagai ketidakpastian yang ada, mengukur kapasitas untuk mencapainya, kemudian memilih arah-arah terbaik untuk mencapainya (Rustiadi dkk., 2009).

\subsubsection{Rencana Tata Ruang Wilayah}

Sebagaimana diamanahkan dalam Undang-undang Nomor 26 Tahun 2007, tata ruang merupakan wujud dari pola ruang dan struktur ruang, dimana pola ruang sangat erat kaitannya dengan istilah-istilah kunci seperti pemusatan, penyebaran, pencampuran dan keterkaitan, serta posisi/lokas. Sementara istilah pola pemanfaatan ruang (atau pola ruang) berkaitan dengan aspek-aspek distribusi (sebaran) spasial sumberdaya dan aktivitas pemanfaatannya menurut lokasi. Secara formal, ekspresi pola pemanfaatan ruang umumnya digambarkan dalam berbagai bentuk peta, seperti peta land use (penggunaan lahan) dan peta land cover (penutupan lahan) adalah bentuk deskripsi terbaik di dalam menggambarkan pola pemanfaatan ruang.

Struktur ruang merupakan gambaran mengenai linkages (hubungan keterkaitan) antara aspek-aspek aktivitas pemanfaatan ruang dan hubungan antar komponen-komponen yang ada pada suatu wilayah. Di dalam interaksi spasial di daratan, secara spasial aspek keterkaitan digambarkan dengan unsur jaringan prasarananya, sarana angkutan, obyek yang dialirkan, besaran aliran, hingga aspek tujuan/maksud dari interaksi yang dituju. Aspek kedua struktur ruang setelah struktur jaringan prasarana adalah aspek struktur pusat-pusat aktivitas 
permukiman. Pada akhirnya, gambaran mengenai kapasitas atau hirarki pusat-pusat dan linkage berimplikasi pada kebutuhan sarana dan prasarana (Rustiadi dkk., 2009).

Perencanaan tata ruang pada dasarnya merupakan suatu bentuk intervensi yang dilakukan guna terwujudnya suatu ruang yang nyaman, produktif dan berkelanjutan sehingga dapat meningkatkan kesejahteraan masyarakat dan terciptanya keseimbangan antar wilayah. Dalam proses perencanaan tata ruang dapat digambarkan dengan suatu pendekatan sistem yang melibatkan input, proses, dan output. Input yang disini merupakan keadaan fisik yang diproses dengan analisis secara integral, baik kondisi saat ini, maupun ke depan untuk masing-masing hirarki tata ruang tingkat nasional, provinsi hingga kabupaten/kota, guna menghasilkan output berupa Rencana Tata Ruang yang menyeluruh dikenal dengan Rencana Tata Ruang Wilayah (RTRW) Nasional, Provinsi dan Kabupaten/Kota. RTRW Kabupaten/Kota merupakan sebuah dokumen rencana tata ruang skala kabupaten/kota dengan muatan kelengkapan infrastruktur dasar di tingkat lokal atau regional yang disesuaikan dengan karakteristik zona-zona pengembangan kawasan yang ada. Pada tataran operasional, RTRW tersebut perlu dikembangkan lagi menjadi Rencana Detail Tata Ruang (RDTR) yang dilengkapi dengan aturan pemanfaatan lahan yang dapat dijadikan dasar dalam pemberian izin dan pengendalian pemanfaatan ruang yang ada (Supriyatno, 2009).

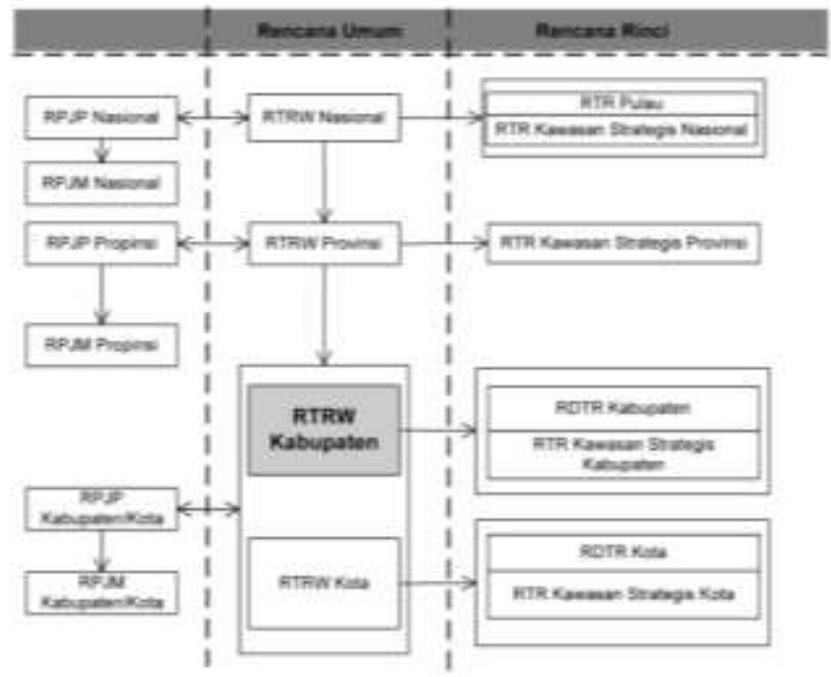

Gambar 1. Kedudukan RTRW kabupaten dalam sistem penataan ruang dan sistem perencanaan pembangunan nasional Sumber: Permen PU No. 16/PRT/M/2009

Dalam pedoman penyusunan rencana tata ruang kabupaten (Peraturan Menteri Pekerjaan Umum Nomor: 16/PRT/M/2009), Kementerian Pekerjaan Umum menyampaikan tentang acuan penyusunan rencana tata ruang wilayah kabupaten, yaitu: 1) RTRW Nasional dan provinsi, 2) Pedoman dan petunjuk pelaksanaan bidang penataan ruang, dan 3) Rencana Pembangunan Jangka Panjang Daerah (RPJPD). Disamping itu, penyusunan rencana tata ruang wilayah kabupaten harus memperhatikan:

1. Perkembangan permasalahan provinsi dan hasil pengkajian implikasi penataan ruang kabupaten;

2. Upaya pemerataan pembangunan dan pertumbuhan ekonomi kabupaten;

3. Keselarasan aspirasi pembangunan kabupaten;

4. Daya dukung dan daya tampung lingkungan hidup;

5. Rencana pembangunan jangka panjang daerah;

6. Rencana tata ruang wilayah kabupaten yang berbatasan; dan

7. Rencana tata ruang kawasan strategis kabupaten.

Adapun muatan yang terkandung dalam RTRW kabupaten adalah:

1. Tujuan, kebijakan, dan strategi penataan ruang wilayah kabupaten;

2. Rencana struktur ruang wilayah kabupaten yang meliputi sistem perkotaan di wilayahnya yang terkait dengan kawasan perdesaan dan sistem jaringan prasarana wilayah kabupaten;

3. Rencana pola ruang wilayah kabupaten yang meliputi kawasan lindung kabupaten dan kawasan budi daya kabupaten;

4. Penetapan kawasan strategis kabupaten;

5. Arahan pemanfaatan ruang wilayah kabupaten yang berisi indikasi program utama jangka menengah lima tahunan; dan 
6. Ketentuan pengendalian pemanfaatan ruang wilayah kabupaten yang berisi ketentuan umum peraturan zonasi, ketentuan perizinan, ketentuan insentif dan disinsentif, serta arahan sanksi.

Setelah dokumen RTRW kabupaten selesai disusun dan disahkan melalui Dewan Perwakilan Rakyat Daerah (DPRD) kabupaten setempat menjadi Peraturan Daerah (Perda), maka RTRW tersebut kemudian menjadi pedoman untuk:

1. Penyusunan rencana pembangunan jangka panjang daerah;

2. Penyusunan rencana pembangunan jangka menengah daerah;

3. Pemanfaatan ruang dan pengendalian pemanfaatan ruang di wilayah kabupaten;

4. Mewujudkan keterpaduan, keterkaitan, dan keseimbangan antar sektor;

5. Penetapan lokasi dan fungsi ruang untuk investasi; dan

6. Penataan ruang kawasan strategis kabupaten.

\subsubsection{Bentuk Kebijakan}

Proses suatu kebijakan yang sebetulnya juga merupakan proses politik yang kompleks untuk dilihat sebagai suatu proses linier formulasi-implementasievaluasi. Melalui sudut pandang proses politik ini, evaluasi hanya merupakan bahan tambahan sebagai penyeimbang pertarungan kepentingan yang dialektis untuk kemudian terjadi keputusankeputusan politik tertentu (Parsons, 1997).

Di dalam studi terhadap suatu kebijakan publik, mau tidak mau dimensi politik menjadi fokus perhatian, karena kebijakan publik merupakan suatu proses pembuatan kebijakan oleh pemerintah atau pemegang kekuasaan yang berdampak pada masyarakat luas. Politik dapat menggambarkan dan mengintegrasikan suatu persoalan kebijakan ada yang muncul ke permukaan dengan cara yang sangat kompleks, yaitu melalui dinamika masyarakat yang melibatkan aspirasinya, konsep diri, kepercayaan dan kemudian mengkonstruksi persoalan-persoalan tertentu (Howlett dan Ramesh, 1998).

Untuk melihat kecepatan perubahan kebijakan kita juga harus melihat aspek ide. Kita harus melihat perubahan pada tingkat ide ini. Bila tidak ada perubahan pada tingkat ini maka bisa dipastikan bahwa perubahan yang terjadi akan berkembang sedikit demi sedikit secara teratur (inkremental).

Tabel 1. Dampak perubahan ide dan kepentingan pada perubahan kebijakan

\begin{tabular}{ccc}
\hline \multirow{2}{*}{$\begin{array}{c}\text { Adanya perubahan } \\
\text { tingkat ide }\end{array}$} & \multicolumn{2}{c}{ Adanya perubahan aktor/kepentingan } \\
\cline { 2 - 3 } Ya & Ya & Tidak \\
\hline Tidak & Paradigmatik cepat & Paradigmatik lambat \\
& Inkremental cepat & Inkremental lambat \\
\hline & Sumber: Howlett dan Ramesh, 1998 &
\end{tabular}

\subsubsection{Perencanaan Adaptif}

Perencanaan ini menggunakan pendekatan yang didasarkan atas proses pengendalian adaptif yang berfokus pada proses pengambilan keputusan yang berdasarkan pengalaman. Pendekatan ini dilakukan seperti apabila diperoleh informasi baru maka segera dilakukan review atas suatu pengelolaan yang sedang berjalan sehingga dirumuskan pendekatan-pendekatan baru berikutnya. Dalam satu pengertian, pendekatan adaptif mencerminkan peleburan perencanaan dengan manajemen yang menekankan pentingnya fleksibilitas dan responsivitas pada level pembuatan keputusan dan rancangan (Dempster, 1998, Wijaatmaja, 2015).

Perencanaan adaptif hanya dapat dilakukan oleh pihak yang memiliki kewenangan luas yang biasanya dimiliki oleh pimpinan tertinggi. Namun pendekatan adaptif menghadapi kendala, terutama akibat adanya penolakan lembaga pengelola atau pihak yang memanfaatkan sumberdaya untuk melakukan penyesuaian terhadap hal-hal yang penuh ketidakpastian. Selain itu, perencanaan adaptif yang terlalu longgar, akan banyak menimbulkan inkonsistensi dalam perspektif jangka panjang yang berpengaruh pada kesinambungan kebijakan perencanaan dan program-program antar waktu yang dapat menyebabkan tidak tercapainya tujuan strategis jangka panjang (Rustiadi, dkk., 2009).

\subsubsection{Perencanaan Transaktif}

Perencanaan transaktif dikembangkan oleh Friedmann sebagai respon terhadap permasalahan yang timbul akibat sentralisasi dalam perencanaan sosial yang didasarkan model rasional komprehensif yang mengabaikan proses. Menurut Friedmann, perencanaan dalam prosesnya harus normatif, politis, transaktif, inovatif dan berdasarkan pembelajaran sosial (Wijaatmaja, 2015). 
Perencanaan ini merupakan pendekatan yang difokuskan pada pengalaman masyarakat dalam mengungkapkan permasalahan kebijakan. Pendekatan ini merupakan evolusi institusi desentralisasi dalam membantu masyarakat mengendalikan proses sosial yang mengatur kesejahteraannya. Menekankan pada harkat individu yang menjunjung tinggi kepentingan pribadi dan bersifat desentralisasi, suatu desentralisasi yang transaktif yaitu berkembang dari individu ke individu secara keseluruhan.

Menurut pendekatan ini, pengetahuan akan bermanfaat dengan baik ketika menghasilkan tindakan yang berkontribusi dalam mempertemukan kebutuhan kelompok masyarakat yang berkepentingan. Prinsip utama perencanaan transaktif adalah pembelajaran bersama melalui kontak langsung dengan para pihak yang dipengaruhi oleh implementasi dari suatu rencana (Sharma, 2008, Wijaatmaja, 2015).

Perencanaan transaktif menempatkan para pihak yang terpengaruhi tersebut dalam proses perencanaan, bersifat partisipatif. Dalam beberapa situasi hal ini secara nyata menguntungkan ketika isu-isu lokal langsung diperoleh dari semua kelompok yang hadir, dan interaksi tatap muka dengan mereka atau kelompok perwakilan mengalami kecocokan (Alexander, 1994, Wijaatmaja, 2015).

\section{Metodologi Penelitian}

\subsection{Rancangan Penelitian}

Penelitian ini memiliki tujuan untuk mengetahui integrasi antara teori dan praktek perencanaan yang mencakup proses dan substansi perencanaan tingkat rencana tata ruang wilayah Kabupaten Kutai Timur, khususnya wilayah ibukotanya, Sangatta, serta dampak dari rencana tersebut pada struktur dan pola ruang, dikaitkan dengan pertumbuhan penduduk yang signifikan selama 10 tahun terakhir. Dengan tujuan tersebut, maka penelitian dilakukan dengan metode kualitatif, dimana format kualitatif dimanfaatkan guna kebutuhan meneliti sesuatu dari segi prosesnya. Serta data yang dikumpulkan berupa kata-kata, gambar dan bukan angkaangka (Moleong, 2008).

Di dalam penulisannya, penelitian ini menggunakan pendekatan penulisan deskriptif, yang bertujuan untuk menggambarkan, meringkas berbagai kondisi, situasi atau fenomena realitas yang menjadi obyek penelitian dan berupaya menarik realitas itu ke permukaan sebagai suatu ciri, karakter, sifat, model, tanda atau gambaran tentang kondisi, situasi ataupun fenomena tertentu (Bungin, 2008).

Rancangan penelitian yang dilakukan ini melalui beberapa tahapan, yakni diawali dengan menentukan permasalahan, menentukan instrumen penelitian, menentukan metode yang dipergunakan mencakup wawancara dan studi dokumentasi. Selanjutnya, tahapan menganalisis data yang sudah terkumpul. Tahap terakhir merupakan kesimpulan serta rekomendasi.

\subsection{Lokasi Penelitian}

Penelitian ini mengambil lokasi di Kabupaten Kutai Timur, khususnya wilayah ibukota Sangatta (Kecamatan Sangatta Utara), dengan ruang lingkup penelitian pada kasus perencanaan tata ruang wilayah kota Sangatta.

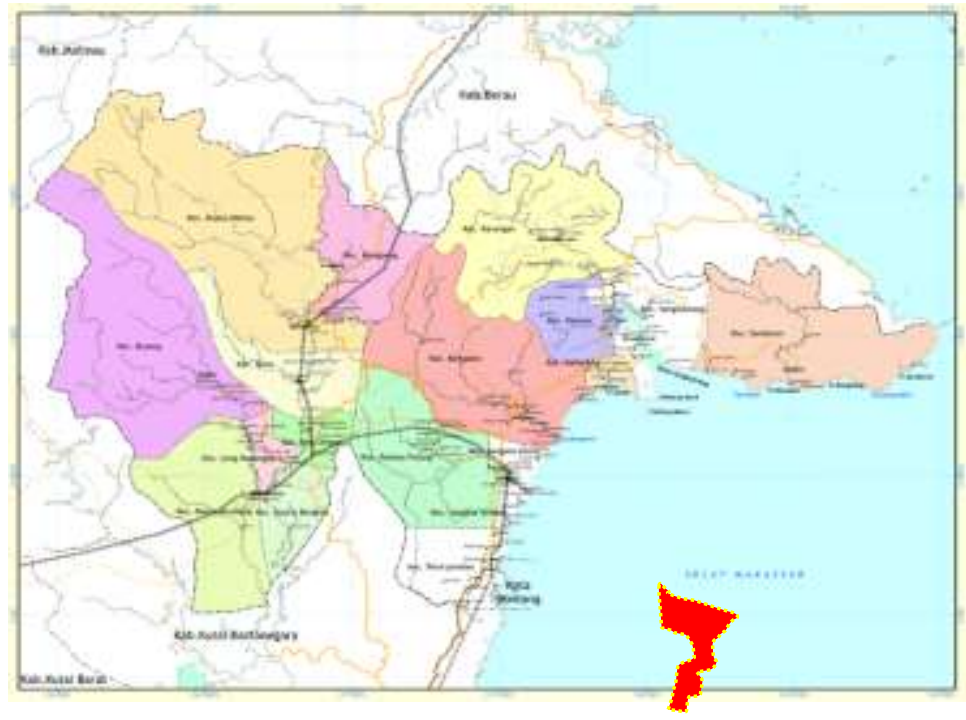

Gambar 2. Peta Kabupaten Kutai Timur dan lokasi penelitian, Kec. Sangatta Utara Sumber: Bappeda Kabupaten Kutai Timur Tahun 2017 


\subsection{Sumber Data}

Sesuai dengan pendekatan penelitian yang dilakukan, maka jenis data yang akan diperoleh adalah data kualitatif yang dinarasikan. Sumber data dapat dibagi menjadi dua yaitu sumber data primer dan sumber data sekunder. Sumber data primer bersumber dari informasi para pemangku kepentingan yang terlibat dalam proses serta memahami substansi perencanaan tata ruang Kabupaten Kutai Timur, meliputi Badan Perencanaan Pembangunan Daerah dan Dinas Pekerjaan Umum Kabupaten Kutai Timur. Sedangkan sumber data sekunder yaitu Peraturan Daerah Kabupaten Kutai Timur Nomor 1 Tahun 2016 tentang Rencana Tata Ruang Wilayah (RTRW) Kabupaten Kutai Timur Tahun 2015-2035, Dokumen RTRW Tahun 2015, serta hasil survey lapangan melihat secara langsung kaitan antara perencanaan dengan kondisi yang ada.

Tabel 2. Jenis dan sumber data

\begin{tabular}{|c|c|c|c|}
\hline Tujuan & Data & Jenis data & Sumber data \\
\hline $\begin{array}{l}\text { Mengetahui pihak-pihak } \\
\text { yang berperan dalam } \\
\text { penyusunan Perda Kutai } \\
\text { Timur No. } 1 \text { Tahun } 2016\end{array}$ & $\begin{array}{l}\text { - Notulen dan berita acara } \\
\text { rapat } \\
\text { - Naskah RTRW. } \\
\text { - Materi teknis RTRW } \\
\text { - Peraturan perundang- } \\
\text { undangan. } \\
\end{array}$ & Kualitatif & $\begin{array}{l}\text { Bappeda Kab. Kutim } \\
\text { DPRD Kab. Kutim }\end{array}$ \\
\hline $\begin{array}{l}\text { Mengetahui pendekatan } \\
\text { yang diterapkan dalam } \\
\text { perencanaan tata ruang } \\
\text { Kabupaten Kutai Timur }\end{array}$ & $\begin{array}{l}\text { - Notulen dan berita acara } \\
\text { rapat } \\
\text { - Media massa } \\
\text { - Naskah RTRW }\end{array}$ & Kualitatif & $\begin{array}{l}\text { Bappeda Kab. Kutim } \\
\text { DPRD Kab. Kutim } \\
\text { Masyarakat/Tokoh }\end{array}$ \\
\hline
\end{tabular}

Sumber: Dokumen pribadi, 2017

\section{Hasil dan Pembahasan}

\subsection{Kondisi sosial kependudukan}

Pada awal dibentuk, Kabupaten Kutai Timur terdiri dari 5 kecamatan namun berdasarkan Peraturan Daerah Provinsi Kalimantan Timur Nomor 16 Tahun 1999, kecamatan di Kutai Timur dimekarkan menjadi 11 kecamatan dan pada Tahun 2005 berdasarkan Peraturan Daerah Kabupaten Kutai Timur Nomor 12 Tahun 2005 dimekarkan lagi menjadi 18 kecamatan.

Tabel 3. Luas wilayah kecamatan dan jumlah penduduk Kabupaten Kutai Timur tahun 2006 dan tahun 2016

\begin{tabular}{llrrrr}
\hline \multirow{2}{*}{ No } & \multirow{2}{*}{ Kecamatan } & \multicolumn{2}{c}{ Luas } & \multicolumn{2}{c}{ Penduduk (Jiwa) } \\
\cline { 3 - 6 } & & \multicolumn{1}{c}{ Ha } & \multicolumn{1}{c}{ \% } & $\mathbf{2 0 0 6}$ & \multicolumn{1}{c}{$\mathbf{2 0 1 6}$} \\
\hline 1 & Muara Ancalong & $238.714,20$ & 7,16 & 11.377 & 13.067 \\
\hline 2 & Busang & $473.626,49$ & 14,20 & 5.446 & 6.174 \\
\hline 3 & Long Mesangat & $35.542,72$ & 1,07 & 3.535 & 7.682 \\
\hline 4 & Muara Wahau & $586.018,54$ & 17,57 & 14.548 & 26.426 \\
\hline 5 & Telen & $138.224,32$ & 4,15 & 5.114 & 11.625 \\
\hline 6 & Kongbeng & $149.511,61$ & 4,48 & 10.769 & 27.997 \\
\hline 7 & Muara Bengkal & $82.197,78$ & 2,46 & 10.336 & 13.832 \\
\hline 8 & Batu Ampar & $48.816,78$ & 1,46 & 4.569 & 7.246 \\
\hline 9 & Sangatta Utara & $27.684,44$ & 0,83 & 51.338 & 119.855 \\
\hline 10 & Bengalon & $357.149,79$ & 10,71 & 15.513 & 43.086 \\
\hline 11 & Teluk Pandan & $95.531,22$ & 2,86 & 8.523 & 16.506 \\
\hline 12 & Rantau Pulung & $135.641,44$ & 4,07 & 7.130 & 10.956 \\
\hline 13 & Sangatta Selatan & $120.363,71$ & 3,61 & 13.621 & 31.429 \\
\hline 14 & Kaliorang & $21.034,62$ & 0,63 & 7.002 & 14.445 \\
\hline 15 & Sangkulirang & $138.254,50$ & 4,15 & 15.532 & 22.831 \\
\hline 16 & Sandaran & $294.600,17$ & 8,83 & 5.989 & 12.146 \\
\hline 17 & Kaubun & $86.078,19$ & 2,58 & 6.710 & 15.700 \\
\hline 18 & Karangan & $305.629,76$ & 9,17 & 5.294 & 14.550 \\
\hline & & $3.334 .620,27$ & 100,00 & 203.156 & 415.553 \\
\hline & & Jumlah & Sumbrap
\end{tabular}

Sumber: Bappeda Kabupaten Kutai Timur Tahun 2017 
Penduduk Kabupaten Kutai Timur yang paling banyak bermukim berada di Kecamatan Sangatta Utara yang sekaligus menjadi ibukota kabupaten tersebut. Pertumbuhan penduduk Kecamatan Sangatta Utara meningat sebesar 57,16\%, dari 51.338 jiwa di tahun 2006 naik menjadi 119.855 jiwa di tahun 2016.

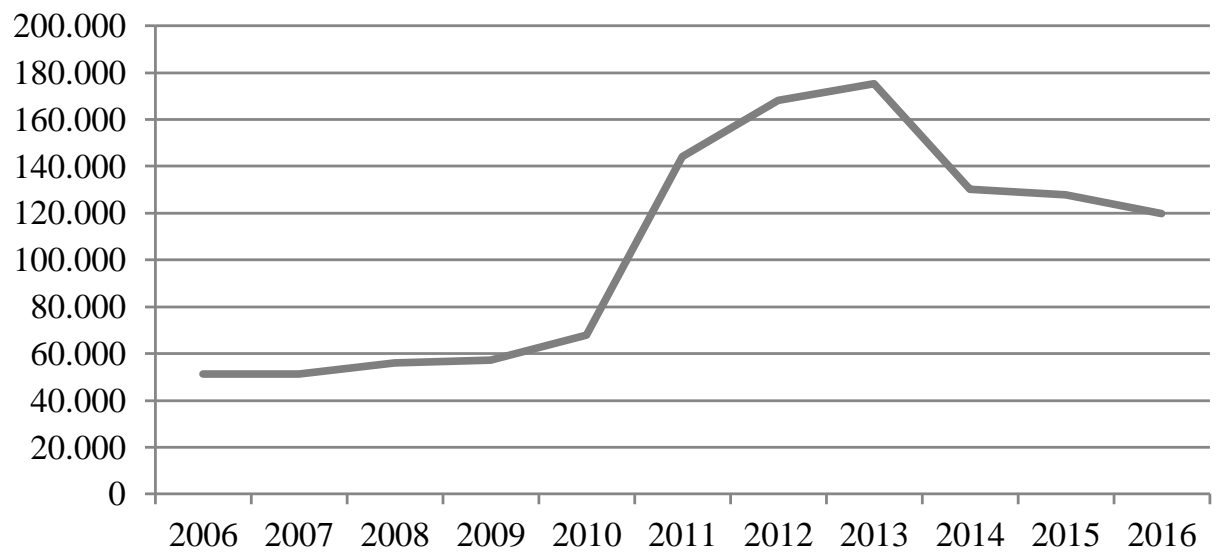

Gambar 3. Grafik pertumbuhan penduduk Kec. Sangatta Utara Tahun 2006-2016 Sumber: Bappeda Kabupaten Kutai Timur Tahun 2017

Salah satu penyebab terjadinya pertumbuhan penduduk yang signifikan tersebut adalah karena wilayah tersebut memiliki potensi kegaitan produksi yang cukup besar, yaitu dengan adanya sumberdaya alam berupa tambang batubara, sehingga mendorong terjadinya aglomerasi pada kecamatan tersebut.

\subsection{Kondisi wilayah perkotaan}

Kota Sangatta memiliki struktur kota linier, dimana perkembangan kotanya sangat kuat di sepanjang poros Jalan Yos Sudarso 1, 2 dan 3 menyebar disepanjang jalan utama tersebut. Wilayah-wilayah permukiman terbentuk seiring dengan pertumbuhan penduduknya.

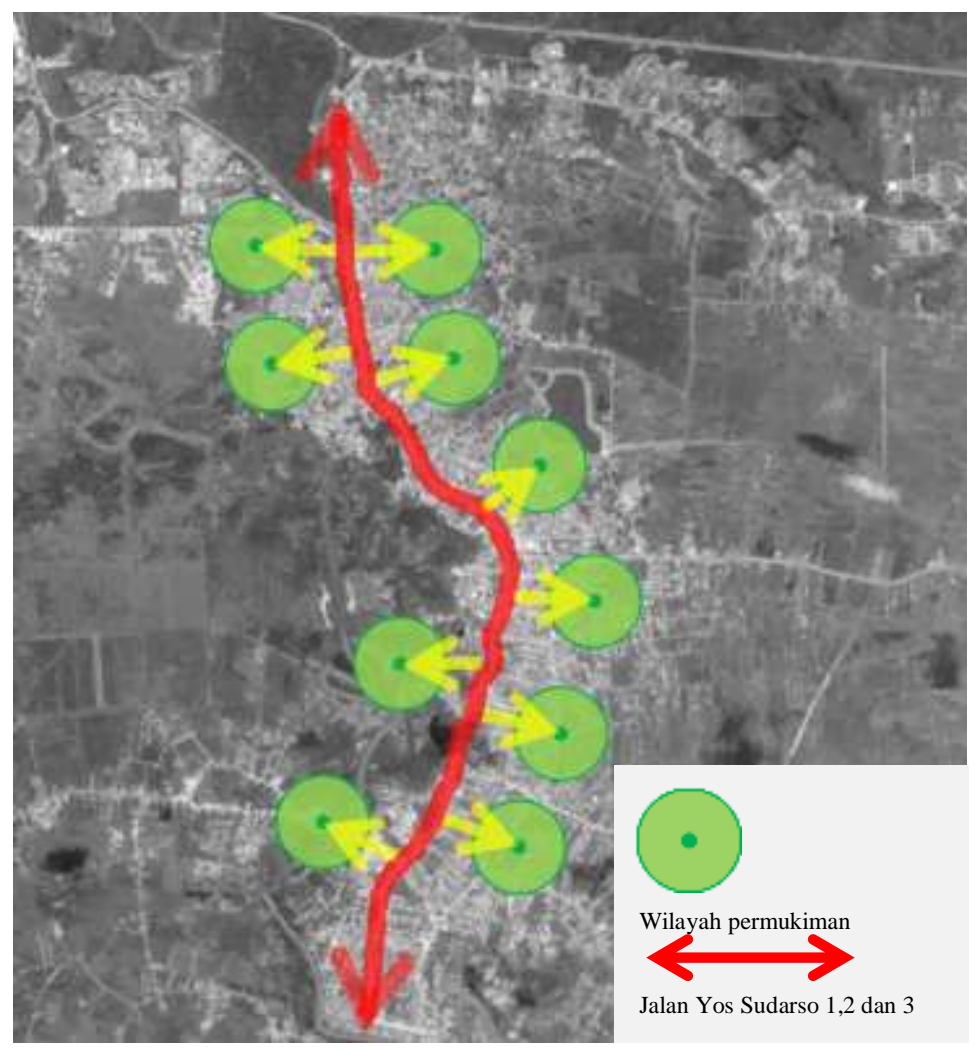

Gambar 4. Foto udara Kota Sangatta Kabupaten Kutai Timur

Sumber: Bappeda Kabupaten Kutai Timur Tahun 2017, Data diolah 
Jika dikaitkan dengan pertumbuhan penduduk Kecamatan Sangatta Utara (wilayah ibukota Sangatta) selama 10 tahun terakhir, dapat diindikasikan bahwa pada awal terbentuknya Kabupaten Kutai Timur, demand penduduk terhadap kota Sangatta tidak sebanding dengan supply, dikarenakan infrastruktur kotanya masih rendah, sehingga wilayah-wilayah permukiman terbentuk tanpa ada perencanaan. Dengan kondisi seperti itu, zona yang terbentuk adalah zona campuran karena memiliki lebih dari 1 (satu) fungsi. Hal ini mengakibatkan ketidakteraturan bentuk kotanya.

Masalah yang kemudian muncul salah satunya berkaitan dengan terganggunya kenyamanan masyarakat yang letak rumahnya berdekatan dengan bangunan budidaya sarang burung walet, akibat suara yang ditimbulkan serta kotorannya yang diduga kuat dapat menyebarkan virus flu burung. Permasalahan yang sudah diterima dan ditindaklanjuti pihak Pemerintah Kabupaten Kutai Timur, namun didalam penangannya di lapangan masih mengalami beberapa kendala.
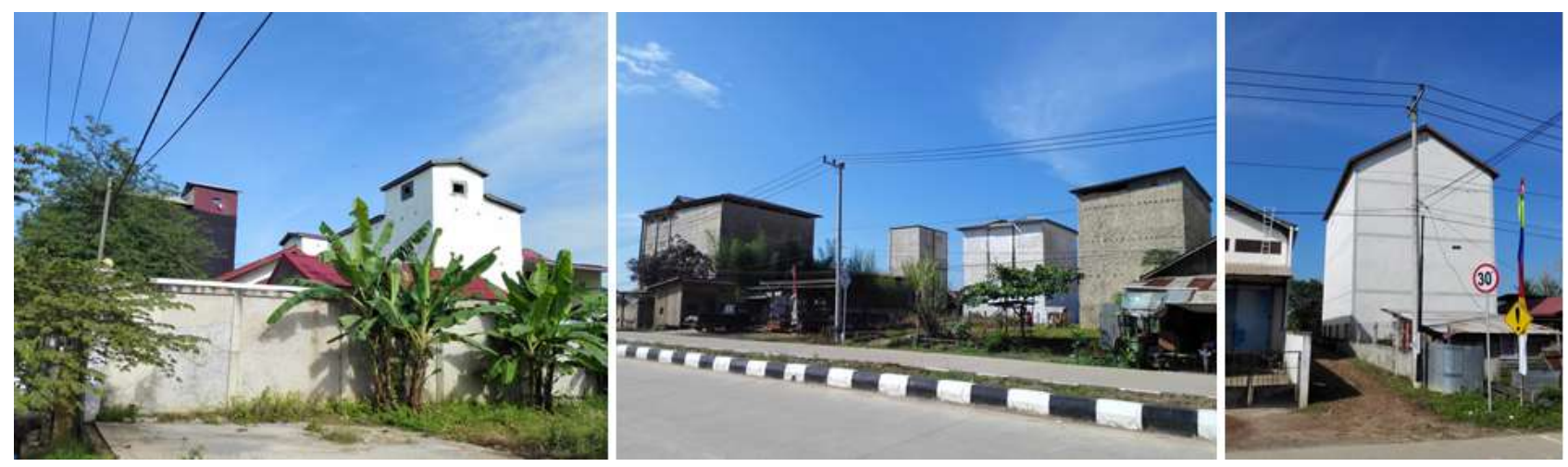

Gambar 5. Sarang burung wallet di wilayah permukiman Kota Sangatta Sumber: Dokumentasi pribadi, 2017

Dalam mengimplementasikan kebijakan pemerintah pusat, berkaitan dengan tata ruang, belum dapat dicapai dalam waktu yang singkat. Sebagian kebijakan pengembangan ruang kota Sangatta tidak sesuai dengan fungsi peruntukan lahannya. Hal ini terlihat saat RTRW Kabupaten Kutai Timur Tahun 2015-2035 selesai disusun dan diperdakan melalui Peraturan Daerah Kutai Timur Nomor 1 Tahun 2016. Disamping kebanyakan zona yang terbentuk adalah zona campuran, beberapa kawasan di wilayah Kecamatan Sangatta Utara dan Kecamatan Sangatta Selatan yang merupakan kawasan konservasi digunakan sebagai pengembangan kawasan permukiman, perdagangan dan jasa.

Ketidaknyamanan dirasakan pula di sepanjang Jalan Yos Sudarso 1, 2 dan 3, dimana ruang terbuka hijau (RTH) sangat kurang. Hal ini juga dirasakan sepanjang pedestrian way yang kurang diteduhi oleh vegetasi, serta ketidakjelasan batas antara jalan dengan pedestrian waynya.

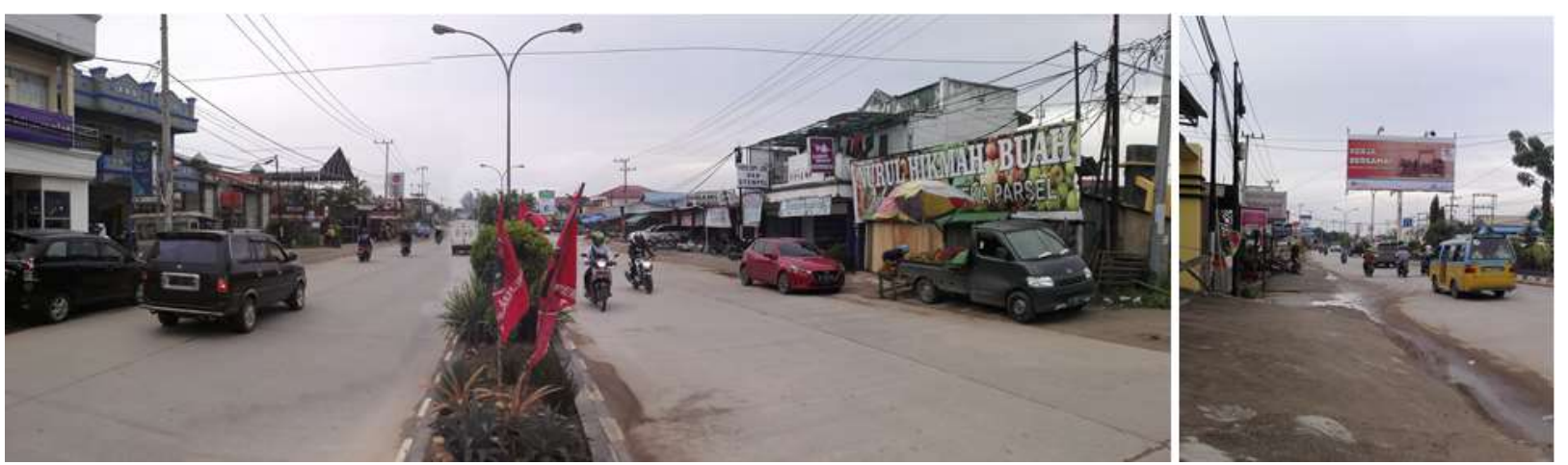

Gambar 6. Jalan Yos Sudarso 1 Kota Sangatta

Sumber: Dokumentasi pribadi, 2017

\section{Kesimpulan}

Berdasarkan hasil analisa, pengamatan dan pembahasan melalui metoda yang digunakan dalam penelitian ini, maka dapat diambil kesimpulan sebagai berikut: 
Pertama, laju pertumbuhan penduduk di Kabupaten Kutai Timur, khususnya di Kecamatan Sangatta Utara walau mengalami penurunan sejak tahun 2014 hingga 2016 akibat harga batubara dunia menurun pada tahun 2014, namun dampak yang sudah diberikan terhadap perkembangan kota Sangatta adalah sejak awal berdirinya Kabupaten Kutai Timur hingga tahun 2013, dimana hutan dan rawa dijadikan wilayah-wilayah permukiman.

Kedua, pertumbuhan penduduk yang signifikan tersebut mengindikasikan tingkat migrasi tinggi namun tidak disertai dengan fasilitas permukiman sebagai supply terhadap demand, sehingga permukimanpermukiman muncul tanpa terencana sebelumnya. Insfrastruktur berbanding terbalik dengan kepadatan penduduk.

Ketiga, dengan lambatnya kebijakan pemerintah terhadap penataan ruang, mengakibatkan terciptanya zona-zona campuran, kurangnya ruang terbuka hijau serta kurang nyamanannya pejalan kaki di sepanjang Jalan Yos Sudarso.

Keempat, dengan berlakunya Peraturan Pemerintah Nomor 1 Tahun 2016 tentang RTRW Kabupaten Kutai Timur Tahun 2015-2035, ditemukan ketidaktepatan antara fungsi kawasan dengan peruntukannya.

Kelima, berkembangnya permukiman di area Taman Nasional Kutai apabila dibiarkan dapat menimbulkan kerusakan lingkuangan.

\section{Referensi}

Alexaneder, E. R. (1994). The Non-Euclidean Mode of Planning: What is It to Be. Journal of the American Planning Association, Vol. 60, No. 3.

Bappeda Kabupaten Kutai Timur (2010). Laporan Keterangan Pertanggungjawaban Akhir Masa Jabatan Bupati Kutai Timur Tahun 2006-2011. Sangatta.

Bappeda Kabupaten Kutai Timur (2015). Laporan Keterangan Pertanggungjawaban Akhir Masa Jabatan Bupati Kutai Timur Tahun 2011-2015. Sangatta.

Badan Pusat Statistik Kabupaten Kutai Timur (2017). Kutai Timur Dalam Angka Tahun 2006-2016. Sangatta. Becker. Gary S., dan Tomes, Nigel (1986). Human Capital and the Rise and Fall of Families. LaborEcon. 4, no. 3, pt. 2: S1-S39.

Bungin, M. (2008). Penelitian Kualitatif. Jakarta: Kencana.

Dempster, M. B. (1998). A Self-Orginaizing Systems Perspective on Planning for Sustainability (tesis). Ontario: University Waterloo.

Dinas Kependudukan dan Pencatatan Sipil Kabupaten Kutai Timur (2016). Kutai Timur Dalam Angka Tahun 2006-2016. Sangatta.

Hirsch, A. R. dan Mohl A. R. (1993). Urban policy in twentieth-century America. New Brunswick, N.J. : Rutgers University Press.

Howlett, M. dan Ramesh, M. (1998). Policy Subsystem Configurations and Policy Change: Operationalizing the Postpositivist Analysis of the Politics of the Policy Process. Policy Studies Journal, Vol. 26, No. 3.

Krier, Rob (1979). Urban Space. Academic Edition: Academy Group Ltd, 42 Leinster Gardens, London.

Moleong, L. J. (2008). Metodologi Penelitian Kualitatif Edisi Revisi. Bandung: PT Remaja Rosdakarya.

Parsons, W. (2005). Public Policy - Pengantar Teori dan Praktik Analisis Kebijakan. (Tri Wibowo Budi Santoso, Pentj). Jakarta: Prenada Media.

Peraturan Daerah Kabupaten Kutai Timur Nomor 12 Tahun 2005 tentang Pemekaran Kecamatan di wilayah Kabupaten Kutai Timur. 2005. Sangatta.

Peraturan Daerah Kabupaten Kutai Timur Nomor 1 Tahun 2016 tentang RTRW Kabupaten Kutai Timur Tahun 2015-2035. 2016. Sangatta.

Peraturan Menteri Pekerjaan Umum Nomor 16/PRT/M/2009 temtang Pedoman Penyusunan Tata Ruang Wilayah Kabupaten. 2009. Jakarta.

Rustiadi, E, dkk. (2009). Perencanaan dan Pengembangan Wilayah. Jakarta: Crestpent Press dan Yayasan Obor Indonesia.

Sharma, V. 2008. Planning for Holistic Sustainability: A Study of Process in Kerala (India) and Sweden (disertasi). Adelaide: The University of Adelaide.

Supriyatno, B. (2009). Manajemen Tata Ruang. Tangerang: CV. Media Berlian.

Tjiptoherijanto P. (1999). Urbanisasi dan Pengembangan Kota di Indonesia. Diskusi "Masalah Metropolitan: Sebuah Tantangan Global yang harus ditanggapi oleh Anggota Parlemen dari segi peradaban kota dan demokrasi”. DPR RI Jakarta, 30 Maret. 
Undang-undang Nomor 47 Tahun 1999 tentang Pembentukan Kabupaten Nunukan, Kabupaten Malinau, Kabupaten Kutai Barat, Kabupaten Kutai Timur dan Kota Bontang. Jakarta.

Undang-undang Nomor 26 Tahun 2007 tentang Penataan Ruang. 2007. Jakarta.

United Nations, Department of Economic and Social Affairs, Population Division (2014). World Urbanization Prospects: The 2014 Revision. UN.

Wijaatmaja, A. Bagus Mahadwijati (2015). Pendekatan Perencanaan Tata Ruang Wilayah di Kota Denpasar (tesis). Program Studi Arsitektur Pascasarjana Universitas Udayana. Denpasar, 30 Maret. 